\title{
Combination therapy of omalizumab with house dust mite immunotherapy in chronic spontaneous urticaria associated with sensitization to dust mites-case series
}

\author{
P C Kathuria ${ }^{1}$, Manisha Rai ${ }^{2}$ \\ From ${ }^{1}$ Director Senior Consultant, ${ }^{2}$ Associate Consultant, Department of Allergy and Asthma National Allergy Center, BLK Super Speciality Hospital, \\ New Delhi, India
}

\begin{abstract}
Chronic spontaneous urticaria (CSU) is a heterogeneous disorder with recurrent pruritic wheals and/or angioedema. The anti-immunoglobulin E (omalizumab) is used in CSU patients resistant to four-fold second-generation anti-histamines. Most clinical trials have experienced relapse after stopping omalizumab treatment. Here, we present a case series of five cases of chronic atopic urticarial concomitant allergic rhinitis and asthma which have shown immunologically significant positivity to Dermatophagoides pteronyssinus and Dermatophagoides farinae. Disease control was achieved (Urticaria Activity Score $7<6$ ) in four cases by combination therapy of omalizumab with house dust mite (HDM) Allergen Immunotherapy (AIT) and remained sustained for three years on follow-up even after discontinuation of AIT for one year. We hypothesize that this combined therapy may contribute to enhanced clinical efficacy, safety, and faster achievement of disease control in CSU.
\end{abstract}

Key words: Angioedema, Chronic spontaneous urticarial, House dust mite, Omalizumab, Urticaria activity score

$\mathrm{C}$ hronic urticaria $(\mathrm{CU})$ is defined as spontaneous wheals occurring over a duration of longer than six weeks. The prevalence of Chronic Spontaneous Urticaria (CSU) has been estimated to range from 0.5 to $5 \%$ in the general population [1]. Autoallergy and autoimmunity have been suggested to be a frequent cause of CSU [2,3]. Increased total Immunoglobulin E ( $\mathrm{IgE}$ ), increased blood eosinophil, sensitization to house dust mite (HDM) aeroallergens, and IgG autoantibody to FceRI, suggests the value of IgE inflammation in the pathogenesis of CSU. Even though the Skin Prick Test (SPT) was positive for aero-allergens in $38.5 \%$ of CSU patients in 16 studies, it is still not considered as a relevant test to diagnose IgE-mediated CSU. Allergen immunotherapy (AIT) is a relatively safe and effective treatment for allergic rhinitis, conjunctivitis, asthma, stinging insect hypersensitivity, and even atopic dermatitis but the role of AIT for CSU is unclear. Whether sensitization to aeroallergens and HDM is associated with causative factors of CSU is not known because of limited and inconsistent data available. Xing et al., treated 2855 patients who had CU and dust mite allergy with immunotherapy with good to excellent results with the efficacy of $91.1 \%(226 / 248)$ with $66.1 \%$ of excellent or good results [4].

\section{Access this article online}

Received - 24 September 2021

Initial Review - 09 October 2021

Accepted - 21 October 2021

DOI: $10.32677 /$ ijcr.v7i11.3107
Here, we report a case series of five cases of chronic atopic urticarial (CAU), a subgroup of CSU who were immunologically significantly positive to HDM (Dermatophagoides pteronyssinus $[\mathrm{DP}] /$ Dermatophagoides farinae $[\mathrm{DF}])$. Four of these cases were given combined HDM AIT maximum tolerated dose (MTD) $250 \mathrm{BU}$ along with injection omalizumab $150 \mathrm{mg}$ every four weeks. We hypothesize that this combined therapy is the most effective treatment. To the best of our knowledge, no similar case reports have been documented.

\section{CASE SERIES}

\section{Case 1}

A 47-years-old female reported to the department with a history of spontaneously occurring recurrent pruritus and wheals occurring on various body parts along with allergic rhinitis for the past 21 years. The patient was a case of hypothyroidism. She was diagnosed as a case of CSU. There was no improvement (Urticaria Activity Score [UAS] 7 was 28) even after increasing the doses of cetirizine to four-fold (up to $40 \mathrm{mg}$ ) and five courses of oral corticosteroids (OCS) during exacerbations per year. Her total IgE-9.7 IU/ml, absolute eosinophil count-1404 cells/ $\mu \mathrm{L}$, and SPT was positive (wheal size) for DP-6 mm, DF-6 mm (Table 1).

Correspondence to: P C Kathuria, Department of Allergy and Asthma National Allergy Center, BLK Super Speciality Center, New Delhi, India. E-mail: pc_kathuria@yahoo.com

(C) 2021 Creative Commons Attribution-NonCommercial 4.0 International License (CC BY-NC-ND 4.0). 
Table 1: Clinical characteristics of the five cases

\begin{tabular}{|c|c|c|c|c|c|c|c|c|c|c|c|}
\hline Case & Age/Sex & $\begin{array}{c}\text { Disease } \\
\text { duration }\end{array}$ & Total IgE & Other diagnosis & $\begin{array}{l}\text { SPT } \\
\text { Wheal } \\
\text { size }\end{array}$ & $\begin{array}{l}\text { Specific } \\
\text { IgE kUA/L }\end{array}$ & $\begin{array}{l}\text { Duration of } \\
\text { AIT+Omali }\end{array}$ & $\begin{array}{l}\text { Cortisol, } \\
\text { Total }\end{array}$ & $\begin{array}{l}\text { Eosinophil } \\
\text { and AEC }\end{array}$ & \multicolumn{2}{|c|}{$\begin{array}{c}\text { UAS } 7 \\
\text { before } \\
\text { and } \\
\text { after }\end{array}$} \\
\hline 1 & 47 years $/ F$ & 21 years & $9.7 \mathrm{IU} / \mathrm{mL}$ & $\begin{array}{l}\text { AR High } \\
\text { anti-thyroid } \\
\text { antibodies }\end{array}$ & $\begin{array}{l}\text { DP } 6 \mathrm{~mm} \\
\text { DF } 6 \mathrm{~mm} \\
\text { Dog } 5 \mathrm{~mm}\end{array}$ & $\begin{array}{l}\text { Neg } \\
\text { Neg } \\
\text { Neg }\end{array}$ & $\begin{array}{l}1 \text { year+6 Inj } \\
\text { Omali }\end{array}$ & $24.4 \mathrm{ug} / \mathrm{dL}$ & $\begin{array}{l}9.2 \% \text { and } \\
1404 \text { cells/uL }\end{array}$ & 28 & 5 \\
\hline 2 & 52 years $/ M$ & 2 years & $711 \mathrm{IU} / \mathrm{mL}$ & $\begin{array}{l}\text { AR } \\
\text { AA } \\
\text { HPA suppression }\end{array}$ & $\begin{array}{l}\text { DP } 5 \mathrm{~mm} \\
\text { DF } 5 \mathrm{~mm}\end{array}$ & $\begin{array}{l}\text { Neg } \\
\text { Neg }\end{array}$ & $\begin{array}{l}1 \text { year+9 Inj } \\
\text { Omali }\end{array}$ & $2.96 \mathrm{ug} / \mathrm{dL}$ & $\begin{array}{l}3.5 \% \text { and } \\
220 \text { cells/uL }\end{array}$ & 26 & 4 \\
\hline 3 & 51 years $/ F$ & 10 years & $3604 \mathrm{IU} / \mathrm{mL}$ & $\begin{array}{l}\text { AR } \\
\text { AA } \\
\text { Drug allergy }\end{array}$ & $\begin{array}{l}\text { DP } 6 \mathrm{~mm} \\
\text { DP } 6 \mathrm{~mm}\end{array}$ & $\begin{array}{l}0.49 \\
0.73\end{array}$ & $\begin{array}{l}1 \text { year+9 Inj } \\
\text { Omali }\end{array}$ & $9.6 \mathrm{ug} / \mathrm{dL}$ & $\begin{array}{l}2.5 \% \& \\
185 \text { cells/uL }\end{array}$ & 34 & 4 \\
\hline 4 & 8 years $/ \mathrm{M}$ & 7.5 years & $139 \mathrm{IU} / \mathrm{mL}$ & $\begin{array}{l}\text { Angioedema } \\
\text { AA } \\
\text { AR } \\
\text { Food allergy } \\
\text { HPA suppression }\end{array}$ & $\begin{array}{l}\text { DP } 7 \mathrm{~mm} \\
\text { DF } 6 \mathrm{~mm}\end{array}$ & $\begin{array}{l}\text { Neg } \\
\text { Neg }\end{array}$ & $\begin{array}{l}1 \text { year+9 Inj } \\
\text { Omali }\end{array}$ & $4.6 \mathrm{ug} / \mathrm{dL}$ & $\begin{array}{l}25.6 \% \text { and } \\
1997 \text { cells/uL }\end{array}$ & 30 & 3 \\
\hline 5 & 67 yeras/F & 20 years & $1100 \mathrm{IU} / \mathrm{mL}$ & $\begin{array}{l}\text { AR } \\
\text { AA } \\
\text { Contact urticaria } \\
\text { HPA } \\
\text { Suppression }\end{array}$ & $\begin{array}{l}\text { DP } 6 \mathrm{~mm} \\
\text { DF } 6 \mathrm{~mm}\end{array}$ & $\begin{array}{l}37.8 \mathrm{kUA} / \mathrm{L} \\
65.5 \mathrm{kUA} / \mathrm{L}\end{array}$ & $\begin{array}{l}\text { AIT C/I } \\
\text { (anaphylaxis) } \\
10 \text { Inj Omali }\end{array}$ & $4.17 \mathrm{ug} / \mathrm{dL}$ & $\begin{array}{l}2.4 \% \text { and } \\
200 \text { cells/uL }\end{array}$ & 32 & 28 \\
\hline
\end{tabular}

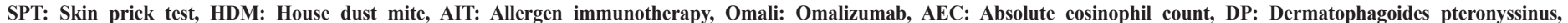

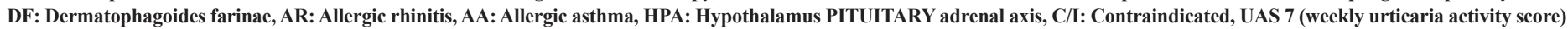

The treatment was initiated with combined HDM AIT along with omalizumab. Disease control was achieved within three months and was maintained for one year (UAS 7 improved to 5). Disease control was sustained during three years follow-up without any adverse events (AEs).

\section{Case 2}

A 52-years-old male presented with complaints of recurrent wheals associated with intense itching all over the body with on and off sneezing and wheezing on dust exposure for the past 2 years. He was diagnosed as a case of CSU associated with allergic rhinitis/asthma. There was no improvement in his symptoms with increasing doses of anti-histamines and OCS (UAS 7 was 26). His total IgE-717 IU/ml, absolute eosinophil count -220 cells/ $\mu \mathrm{L}$, and SPT was positive for DP-5 mm, DF- $5 \mathrm{~mm}$ (Table 1). He was given combined HDM AIT with Omalizumab. Disease control was achieved within four months of initiating treatment (UAS 7 improved to 4) and was sustained for three years on follow-up.

\section{Case 3}

A 51-years-old female presented with complaints of recurrent hives, skin rash after the intake of a drug (nonsteroidal antiinflammatory drugs), sneezing, and wheezing for the past 10 years. She was diagnosed a case of CSU associated with allergic rhinitis and drug allergy. She had no improvement with oral histamines and immunosuppressants (OCS and HCQS) (UAS 7 was 34). Her total $\mathrm{IgE}-3604 \mathrm{IU} / \mathrm{ml}$, absolute eosinophil count-185 cells $/ \mu \mathrm{L}$, specific IgE was positive for DP-0.49 kUA/L, DF- $0.73 \mathrm{kUA} / \mathrm{L}$ and SPT was positive for DP-6 mm, DF-6 mm (Table 1). She was given HDM AIT with omalizumab and she achieved disease control within 5 months (UAS 7 decreased to 4) which was maintained for three years on follow-up.

\section{Case 4}

An 8-years-old male child presented with complaints of oral itching, lip edema, and hives on various parts of the body after intake of raw fruits (apple and peach) along with sneezing and wheezing on exposure to dust since he was six months old. He was diagnosed as CSU associated with allergic rhinitis, asthma, and food allergy. He had been on regular anti-histamines, nebulization with inhaled corticosteroids/Long-acting beta-agonists, and OCS as per need with no improvement (UAS 7 was 30). His total IgE-139 IU/ml, absolute eosinophil count-1997 cells/ $\mu \mathrm{L}$ and SPT was positive (wheal size) for DP-7 mm, DF-6 mm (Table 1). He was given HDM AIT with omalizumab and disease control (UAS 7 decreased to 3) was achieved in three months and was maintained for three years on follow-up without any AEs.

\section{Case 5}

A 67-years-old female presented with a history of spontaneously occurring recurrent pruritus, wheals occurring on various body parts along with itchy eyes, sneezing, running nose, and dyspnea on exposure to dust for the past 20 years. She was diagnosed as a case of CSU associated with contact urticaria, allergic rhinitis, and asthma. The symptoms were poorly controlled even after 
anti-histamines, cyclosporine, and low dose OCS (UAS 7 was 32). Her total IgE- $1100 \mathrm{IU} / \mathrm{ml}$, absolute eosinophil count- 200 cells $/ \mu \mathrm{L}$, specific IgE was positive for DP-37.8 kUA/L, DF-65.5 kUA/L, and SPT was positive (wheal size) for DP-6 mm, DF-6 mm (Table 1). She had an anaphylactic reaction to the first dose of HDM AIT so, only Omalizumab was given for 10 months but she responded poorly (UAS 7 reduced to 28). She was diagnosed as the omalizumab-resistant phenotype of CSU.

\section{DISCUSSION}

CSU is an immune-mediated disorder that affects $1 \%$ of the general population. This chronic condition is associated with various comorbidities, decreased quality of life, and reduced ability to maintain normal activities. There are two endotypes of CSU, Type 1 autoimmune CSU-mediated by IgE antibodies to auto-allergens (auto-allergic) and Type IIb autoimmune CSU-mediated by autoantibodies that target activating mast cell receptors. High total IgE levels (associated with Type I autoimmunity) were related to omalizumab responsive vs. omalizumab resistant CSU phenotype ( $18 \%$ vs. $41 \%$, respectively) while concomitant autoimmunity (which may support Type II autoimmunity) was related to resistant-CSU phenotype (55\% vs. $20 \%$, respectively) $[5,6]$.

Dietary elimination, antihistamines, and corticosteroids only provide symptomatic relief. Omalizumab was approved for the treatment of CSU in August 2014. The international guidelines on CSU recommend to "treat CSU until it is gone." The use of second-generation antihistamine $(\mathrm{SgAH})$ at the licensed dose is recommended as the first-line treatment in CSU and updosing of this $\mathrm{SgAH}$ up to four-fold is recommended in treatmentresistant patients. The humanized anti-IgE mAB-Omalizumab is recommended as the only third-line treatment option and is an effective treatment for patients with CSU with any of the 3 phenotypes (wheals only, angioedema only, and wheals plus angioedema) in an effective dose of $300 \mathrm{mg}$, every four weeks till remission of CSU is achieved (weekly UAS 7 of 0 ). ${ }^{7} \mathrm{~A}$ retrospective observational study reported that at the end of 3 -month therapy, UAS 7 of 6 or less was achieved in 43 and 16 of the 79 previously partial responders or non-responders (UAS $7>7$ ) patients with 450 and $600 \mathrm{mg} / 4$ weeks, respectively [7,8]. Twenty patients did not achieve disease control despite high doses. In another study, 50 of 78 patients with CSU with partial response to omalizumab $300 \mathrm{mg} / 4$ weeks became responders after up dosing to $450 \mathrm{mg} / 4$ weeks [9]. Omalizumab is considered as an add-on treatment to sgAHs in CSU. However, it has been shown to be effective without the need for concomitant sgAH treatment in up to $60 \%$ of patients included in 16 studies [10]. Recent studies have shown that up to $61 \%$ of patients will experience clinical worsening after omalizumab discontinuation, even if the treatment was maintained for one year [11-13].

Our five cases of CAU were associated with allergic rhinitis and asthma were sensitized to HDM (positive SPT to DP and DF). Four of these cases were given HDM AIT with increasing concentration by cluster doses till MTD was achieved during the build-up phase. We could achieve 250 BU of HDM as MTD for one year along with the injection of omalizumab $150 \mathrm{mg}$ every four weeks for 6-10 months. Disease control was achieved in four cases (UAS-7 for assessing disease activity [Disease control (UAS $7<6$ ), Disease remission (UAS $7=0$ )] according to the EAACI/GA ${ }^{2} \mathrm{LEN} / \mathrm{EDF} / \mathrm{WAO}$ guidelines). Case 5 got anaphylaxis with the first dose of HDM AIT. AIT could not be continued, and she was given only omalizumab for 10 months, but disease control could not be achieved despite adding cyclosporin at $2 \mathrm{mg} / \mathrm{kg}$ and was diagnosed as an omalizumab-resistant phenotype ofCSU. It could be because of associated co-morbidities (Hypothalamic-pituitary-adrenal suppression, contact urticarial, and poorly controlled asthma).

Dust mites' allergies have been hypothesized as important pathogenic factors for CSU. Mites are common allergens, colonizing beds, sofas, carpets, and any other woven material. They sensitize and induce atopic diseases. Our four cases (case 1-4) achieved disease control (UAS $7<6$ ) with combined treatment of omalizumab and HDM AIT (MTD $250 \mathrm{BU}$ ) for one year. We speculate that $30-40 \%$ of the patients suffering from HDM induced CAU, a subgroup of CSU with concomitant allergic rhinitis and asthma benefitted with combined AIT with omalizumab. Omalizumab has a synergistic effect with a reduction of allergenicity while AIT induces anti-inflammatory effect, T-cell tolerance by decreased allergen-induced proliferation and production of T-regulatory cells. The combination of AIT and omalizumab resulted in prolonged inhibition of allergen-specific IgE binding which might contribute to enhanced clinical efficacy, safety, and faster achievement of Maximum tolerance dose (MTD $250 \mathrm{BU}$ ) during the build-up phase of HDM allergen vaccine. The authors have published case series on clinical efficacy and safety of combined HDM subcutaneous immunotherapy and omalizumab in allergic rhinitis and asthma [14].

\section{CONCLUSION}

Current evidence indicated that CAU, a subgroup of CSU is an IgE-mediated disease. Our approach of combining omalizumab with HDM AIT is for patients with a long-standing history of $\mathrm{CSU}$, poorly responding to standard conventional therapy as per urticaria guidelines. Our five cases have a strong association of CSU with HDM sensitization. We could achieve disease control in four cases. Further studies are required to better understand the etiopathogenesis of this disease.

\section{ACKNOWLEDGMENT}

The authors would like to thank Dr Gagandeep Momi for providing assistance in reviewing this manuscript.

\section{REFERENCES}

1. Sussman G, Hebert J, Barron C, Bian J, Caron-Guay RM, Laflamme S, et al. Real-life experiences with omalizumab for the treatment of chronic 
urticaria. Ann Allergy Asthma Immunol 2014;112:170-4.

2. Pozderac I, Lugović-Mihić L, Artuković M, Stipić-Marković A, Kuna M, Ferček I. Chronic inducible urticaria: Classification and prominent features of physical and non-physical types. Acta Dermatovenerol Alp Pannonica Adriat 2020;29:141-8.

3. da Silva DM, Vieira TM, Pereira AM, de Sousa Moreira AM, Delgado JL. Crossreactive LTP sensitization in food-dependent exercise-induced urticaria/ anaphylaxis: A pilot study of a component-resolved and in vitro depletion approach. Clin Transl Allergy 2016;6:46.

4. Xing DR, Wen TH, Yu YL, Wei ZP. Urticaria in relation to mite sensitivity and immunotherapy with Injection dermatophagoidei farinae. Zhongguo Ji Sheng Chong Xue Yu Ji Sheng Chong Bing Za Zhi 2008;26:422-7.

5. Maoz-Segal, Levy T, Haj-Yahia S, Offengenden I, Iancovich-Kidon M, Agmon-Levin N. Combination therapy with omalizumab and an immunesuppressive agent for resistant chronic spontaneous urticaria-a real-life experience World Allergy Organ J 2020;13:100448.

6. Shalom G, Magen E, Dreiher J, Freud T, Bogen B, Comaneshter D, et al. Chronic rrticaria and atopic disorders: A cross-sectional study of 11271 patients. Br J Dermatol 2017;177:e96-7.

7. Türk M, Carneiro-Leão L, Kolkhir P, Bonnekoh H, Buttgereit T, Maurer M. How to treat patients with chronic spontaneous urticaria with omalizumab: Questions and answers. J Allergy Clin Immunol Pract 2020;8:113-24.

8. Curto-Barredo L, Spertino J, Figueras-Nart I, Exposito-Serrano V, Guilabert A, Mele-Ninot G, et al. Omalizumab updosing allows disease activity control in patients with refractory chronic spontaneous urticaria. $\mathrm{Br}$ J Dermatol 2018;179:210-2.

9. Vadasz Z, Tal Y, Rotem M, Shichter-Confino V, Mahlab-Guri K, Graif Y, et al. Omalizumab for severe chronic spontaneous urticaria: Real-life experiences of 280 patients. J Allergy Clin Immunol Pract 2017;5:1743-5.

10. Bernstein JA, Kavati A, Tharp MD, Ortiz B, MacDonald K, Denhaerynck K, et al. Effectiveness of omalizumab in adolescent and adult patients with chronic idiopathic/spontaneous urticaria: A systematic review of 'realworld' evidence. Expert Opin Biol Ther 2018;18:425-48.

11. Maurer M, Kaplan A, Rosén K, Holden M, Iqbal A, Trzaskoma BL, et al. The XTEND-CIU study: Long-term use of omalizumab in chronic idiopathic urticaria. J Allergy Clin Immunol 2018;141:1138-9.e7.

12. Türk M, Yılmaz I, Bahçecioglu SN. Treatment and retreatment with omalizumab in chronic spontaneous urticaria: Real life experience with twenty-five patients. Allergol Int 2018;67:85-9.

13. Labrador-Horrillo M, Valero A, Velasco M, Jauregui I, Sastre J, Bartra J, et al. Efficacy of omalizumab in chronic spontaneous urticaria refractory to conventional therapy: Analysis of 110 patients in real-life practice. Expert Opin Biol Ther 2013;13:1225-8.

14. Kathuria PC, Rai M. Clinical efficacy and safety of combined house dust mite subcutaneous immunotherapy and omalizumab in five cases of allergic rhinitis and asthma. Indian J Med Spec 2021;12:175-8.

Funding: None; Conflict of Interest: None Stated.

How to cite this article: Kathuria PC, Rai M. Combination therapy of omalizumab with house dust mite immunotherapy in chronic spontaneous urticaria associated with sensitization to dust mites-case series. Indian J Case Reports. 2021;7(11):469-472. 